\title{
A CIÊNCIA DAS MULHERES: RELAÇÕES ENTRE TEXTO E IMAGEM NA REVISTA UNESP CIÊNCIA
}

\author{
THE WOMEN'S SCIENCE: \\ RELATIONS BETWEEN TEXT AND IMAGE IN THE UNESP CIENCIA \\ MAGAZINE
}

\author{
Bruno Sampaio Garrido ${ }^{1}$ \\ UNESP - Universidade Estadual Paulista (FCLAr)
}

\begin{abstract}
RESUMO: Este trabalho pretende investigar as relações entre os elementos verbais e não verbais de uma reportagem de capa da revista Unesp Ciência, e como elas atuam na construção do sentido global das mensagens produzidas, de maneira a evidenciar os conteúdos tratados no texto, tornando-a mais atraente para os leitores. Para a análise, escolheu-se a capa e a reportagem principal da edição 17 da revista, publicada em março de 2011, que abordam as dificuldades das mulheres cientistas em ocupar cargos mais altos na carreira acadêmica. O corpus foi analisado à luz da semiótica francesa, de maneira a se obter uma compreensão global das mensagens constituintes dos elementos estudados e das relações fundamentais para a construção de sentidos. Como principais resultados, verificou-se que a temática retratada no objeto é articulada para arrebatar mais facilmente o leitor para motivá-lo a continuar a leitura, valendo-se de elementos mais concernentes com o repertório cognitivo-cultural médio do público-alvo, tal como retratar a desigualdade entre homens e mulheres na carreira acadêmica sob a metáfora de uma competição esportiva, entre outras figurativizações que remetem ao tema tratado - como o fato de as cientistas acumularem papéis sociais de profissional, mãe e cuidadora do lar.
\end{abstract}

PALAVRAS-CHAVE: texto; imagem; semiótica; leitura; ciência; jornalismo.

ABSTRACT: This study aims at investigating the relations between verbal and nonverbal elements of a cover story of the Unesp Ciencia Magazine, and how they work in the construction of a global sense of the messages produced, so as to highlight the content addressed in the text, making it more attractive to readers. For the analysis, we chose the cover and the lead story for the $17^{\text {th }}$ issue of the magazine, published in March 2011, addressing the plight of women scientists in occupying higher positions in the academic career. The corpus was analyzed in the light of French semiotics, in order to obtain a comprehensive understanding of constituent messages from studied elements and fundamental relations to the construction of meaning. As main results, it was verified that the theme portrayed in the object is articulated to grab the reader more easily for motivating him to continue the reading, drawing on elements pertaining to the cognitive-cultural average repertoire of audience, as portraying the inequality between men and women in academic career under the metaphor of a sports competition, among other figurativizations referring to the theme - like the fact that scientists accumulate social roles of professional, mother and home caretaker.

KEYWORDS: text; image; semiotics; reading; science; journalism.

\footnotetext{
${ }^{1}$ Jornalista, Mestre em Comunicação pela Unesp de Bauru. Doutorando em Linguística e Língua Portuguesa pela Unesp de Araraquara. Assistente de Suporte Acadêmico do Departamento de Psicologia da Unesp de Bauru.
} 


\section{INTRODUÇÃO}

O jornalismo científico situa-se em uma zona fronteiriça bastante tênue entre o discurso científico e o discurso jornalístico e, portanto, assume uma posição intermediária que conjuga características de ambos. De um lado, é um discurso que divulga e fala sobre a ciência, com a finalidade de torná-la mais acessível e palatável para o público leigo. De outro, esse mesmo discurso reconfigura o saber científico sob a perspectiva de um fato, sujeitando-o aos mesmos critérios de captação, formatação e edição de qualquer texto a ser veiculado por um produto de mídia em particular.

Como já observaram Bueno (1998; 2009), Zamboni (1997), Leibruder (2001), Orlandi (2001) e Grillo (2006), sob a lógica produtiva do jornalismo, os conteúdos são tratados como acontecimentos a serem "consumidos" pelos leitores, e o interesse por eles se esvanece ao final do dia, tornando-os descartáveis - ainda que o conhecimento científico, de fato, não pereça. Logo a ciência, nos veículos de comunicação de massa, é um produto de consumo, que precisa receber atrativos para cativar seu público-alvo e ser consumida mais rápida e facilmente.

No caso das revistas jornalísticas, um desses atrativos é a capa, que funciona como o principal chamariz para o assunto central do periódico e vem acompanhada de uma chamada composta por um título e um pequeno texto descritivo. As capas de revista ajudam não apenas a evidenciar e ilustrar os conteúdos a serem tratados na reportagem principal, mas também agem como um atraente cartão de visitas, uma forma de tornar aquele conteúdo, a princípio estritamente técnico e distante do cidadão comum, mais acessível e potencialmente interessante a um número maior de potenciais leitores. Ou seja, nas palavras de Hernandes (2012), procura-se arrebatar o leitor com o máximo de informações possíveis em um todo significante para cativá-lo desde o primeiro contato, levando-o a consumir a revista.

Essas considerações se estendem à diagramação dos textos jornalísticos. Muito mais do que um apelo estético, as diferentes combinações entre os formantes verbais e não verbais resultam em conjuntos significantes, valorizando (ou não) os conteúdos informativos presentes no texto jornalístico, assim como gerando novos efeitos de sentido que, dependendo da maneira como esses arranjos ocorrem, resultam na sobreposição entre texto e imagens, gerando um terceiro objeto com valor significativo próprio, resultante de uma operação sincrética (HERNANDES, 2012).

O objetivo deste artigo é analisar as relações entre elementos verbais e não verbais presentes em uma reportagem de capa da revista e como eles atuam na construção do sentido global das mensagens produzidas. O corpus será submetido a uma análise descritiva conforme o referencial teórico-metodológico da semiótica francesa, tal como preconiza Greimas (1979), Greimas e Courtés (2008) e autores de mesma filiação, de maneira a se obter uma compreensão global das mensagens constituintes das capas do periódico, assim como as relações entre elementos verbais e não verbais fundamentais para a construção de sentidos.

Para este trabalho, escolhemos uma reportagem da revista Unesp Ciência, que é editada pela assessoria de comunicação da Universidade Estadual Paulista (Unesp) desde setembro de 2009, com a finalidade de divulgar a ciência produzida na e pela instituição. Trata-se da reportagem de capa da edição 17, publicada em março de 2011, que aborda uma temática peculiar: o aumento da participação feminina no meio acadêmico nacional (a ponto de atingir $50 \%$ do contingente de cientistas no Brasil) e, por outro lado, a dificuldade das mulheres cientistas em ocupar cargos mais altos na carreira. 


\section{SEMIÓTICA FRANCESA: UMA BREVE REVISÃO}

A semiótica francesa, tal como elaborada por Greimas (1979; 1981), configura-se como uma robusta abordagem teórico-metodológica voltada para a descrição das relações de sentido que constituem qualquer tipo de texto, independentemente da natureza do sistema de representação usado (verbal, plástico, sonoro, etc.).

Tributária de Saussure (2006) e Hjelmslev (1975), a semiótica greimasiana considera todas as linguagens, sejam as línguas naturais ou outros sistemas semióticos, como sistemas biplanares, em que se articulam um plano de expressão (matéria sensível, captável pelos sentidos) e um plano de conteúdo (matéria inteligível, conceitual, de apreensão cognitiva). Mediante essa articulação, também chamada por Hjelmslev de função semiótica, as linguagens e outros sistemas semióticos produzem seus significados. São conceitos que se aproximam dos termos significante (imagem acústica, elemento sensível da forma linguística) e significado (conceito, elemento inteligível) advindos da teoria saussureana e posteriormente complexificados pelo linguista dinamarquês e pelos semioticistas.

Além dos conceitos de expressão e conteúdo, também adquirem importância cabal para a semiótica outros dois termos: forma e substância, tomados por Greimas e Courtés (2008) conforme a interpretação dada por Hjelmslev (1975), embora Saussure (2006) também os tenha utilizado. Assim, quando falamos em substância da expressão, nos referimos à matéria constitutiva de uma determinada linguagem (sons, cores, linhas, luzes...), enquanto a substância do conteúdo atém-se ao seu aspecto conceitual. Quando essa substância expressiva é recortada, organizada e sistematizada, sujeita a regras combinatórias, vemos aí a forma da expressão, enquanto as relações significantes decorrentes desses procedimentos, também de combinação, são a forma do conteúdo.

Durante boa parte de sua história, a semiótica greimasiana desenvolveu um modelo analítico que visava descrever, basicamente, a forma do conteúdo das linguagens em estudo. A forma de expressão, até então negligenciada ou tratada superficialmente, somente ganharia merecido destaque a partir da década de 1980, especialmente com Jean-Marie Floch (1985), como veremos mais adiante, mostrando como os significados se articulam por meio de operações sintáticas e semânticas que recobrem desde os elementos mais simples e abstratos (ou profundos) até os mais complexos e concretos (ou superficiais). Consolidou-se, assim, o percurso gerativo de sentido como o principal instrumento da análise semiótica, o qual se estrutura em três níveis, a saber:

Nível fundamental ou axiológico: camada mais profunda da organização do texto, na qual subjazem os elementos axiológicos mínimos que regulam a sintaxe e a semântica textuais. As axiologias a que nos referimos se estabelecem por meio de oposições fundamentais (vida X morte; liberdade X opressão), presentes tanto nos elementos do plano da expressão quanto no plano do conteúdo. Floch (1985) e Pietroforte $(2004 ; 2011)$ apontam que, quando há uma correspondência (homologação) entre elementos axiológicos de ambos os planos, vemo-nos diante de uma relação semissimbólica.

Nível narrativo: nível intermediário do percurso gerativo, constitui-se por um ou mais programas narrativos - estruturas sintáticas que indicam as transformações pelas quais são submetidos os sujeitos da narrativa (fazer e estado). Conforme explicam Greimas (1979), Bertrand (2003) e Lara e Matte (2009), a dinâmica se dá pela ação dos actantes, forças transformadoras ou sujeitas à transformação - simplificadas pelo mestre lituano em sujeito (os agentes da narrativa), destinador (o ente que delega ao sujeito os mecanismos de transformação) e objeto (aquilo que é perseguido pelos sujeitos, assumindo a face de um objeto-valor). Há também as figuras do antissujeito e do antidestinador, com os quais os 
actantes se enfrentam, via polêmica ou contratual. Essa relação de confronto entre sujeito e antissujeito, que buscam um mesmo objeto-valor e, diante disso, entram em disputa (polêmica, mais combativa e tensa; transacional, que envolve trocas) define o percurso narrativo. A obtenção do objeto-valor pelo sujeito é chamada de conjunção e o distanciamento do sujeito desse objeto chama-se disjunção. Os diversos momentos em que os objetos-valor mudam de mãos ao longo da narrativa garantem a sua progressão.

Nível discursivo: nível mais superficial da estrutura de um texto, em que se articulam as relações lógicas dos níveis anteriores para se transformarem em discurso, isto é, a materialização dessas relações. Nesse nível se manifestam as marcas da enunciação (pessoa, espaço e tempo), os temas e as figuras, que revestem os elementos axiológicos e narrativos e complexificam a unidade textual (BERTRAND, 2003).

Após essa sucinta revisão do arcabouço teórico-metodológico da semiótica francesa, os próximos segmentos deste artigo serão dedicados ao nosso objeto de estudo e, se julgarmos pertinente, detalharemos alguns aspectos mais específicos da teoria greimasiana em paralelo à realização da análise, de modo a tornar mais claros os procedimentos aqui adotados.

\section{ANÁLISE DO CORPUS: DESIGUALDADE DE SEXOS NA UNIVERSIDADE}

Como já dissemos no início, a reportagem de capa que será analisada aqui aborda as dificuldades das pesquisadoras mulheres em conseguir posições mais altas na carreira profissional. Sob os títulos Competição desigual na ciência, o objeto em questão recorre a uma metáfora para ilustrar a reportagem principal da edição 17 de Unesp Ciência (intitulada A ciência das mulheres), em que dois personagens, um homem e uma mulher, caracterizados como cientistas, competem entre si para alcançar o primeiro lugar em uma corrida - no caso, o homem supera a mulher e vence a disputa.

Os procedimentos de análise adotados neste artigo seguirão o seguinte percurso: em primeiro lugar, começaremos por abordar as estruturas semionarrativas, que envolvem tanto as axiologias estruturantes de todo o percurso gerativo de sentido quanto as relações transformadoras no conjunto textual e dos actantes envolvidos, dando ênfase aos seus predicados modais e, dentro dos limites do texto, seus elementos patêmicos. Já no nível discursivo, iremos abordar os termos mais superficiais e complexos, especialmente no que tange às figurativizações presentes no corpus. Por fim, voltaremos a nossa atenção para as relações semissimbólicas dos elementos do plano da expressão com as categorias lógicas do plano do conteúdo, reveladas na análise precedente.

\section{AS ESTRUTURAS SEMIONARRATIVAS: AÇÕES, ESTADOS E PAIXÕES}

Em primeiro lugar, começaremos nosso trabalho com a análise do nível axiológico ou fundamental dos objetos em estudo, cujo objetivo é descrever as relações lógicas fundamentais que regem o sentido global do texto, e complexificadas nos demais níveis analíticos (narrativo e discursivo). Essas relações mais profundas baseiam-se em elementos semânticos mínimos que se contrapõem, formando oposições fundamentais. Um texto minimamente complexo pode suportar uma rede constituída por várias dessas oposições - ainda que exista uma axiologia tida como central.

Conforme Bertrand (2003) e Lara e Matte (2009), a relação existente entre os termos semânticos das axiologias do nível fundamental tem como elemento característico a oposição/contrariedade entre dois termos, do mesmo modo como, por exemplo, os conceitos 
vida e morte. Contudo, antes de se estabelecer essa condição, há uma situação intermediária, caracterizada pela negação de um dos termos. Se uma narrativa, independentemente de sua complexidade, tem como componente de sua estrutura fundamental a oposição vida $\mathbf{X}$ morte, no meio desse percurso, há uma condição de não-vida (doença, grandes privações, etc.), que se coloca em contradição/negação à vida, até a trajetória se encerrar com a morte. Dentro dessa lógica, o percurso inverso também é possível, a começar por uma situação de morte que, gradualmente, é contradita por outra de não-morte (recuperação da saúde, cessação das privações...) e termina em uma situação de vida.

No que tange à capa de Unesp Ciência, pudemos verificar que ela possui uma narratividade, ainda que estruturada em apenas um programa narrativo. Esse percurso, como vimos, funda-se em determinados conjuntos de valores que orientam a sua organização interna e concatenam seus elementos significantes. Aqui, a axiologia tida como central é a oposição feminino $\mathbf{X}$ masculino, não porque os personagens da capa são de sexos distintos e estão competindo entre si por algo, mas porque esses termos assumem uma variada carga semântica no contexto apresentado.

O masculino, nesse caso, incorpora valores eufóricos (positivos) e reuniria um número maior de elementos favoráveis ao seu êxito na carreira, como dispor de mais tempo livre para se dedicar ao seu trabalho. Assume, dessa forma, uma característica competitiva, valorizada no meio acadêmico. O feminino, ao contrário, recebe valores disfóricos (negativos), já que, por ter de se preocupar também com sua vida familiar, não apresentaria o mesmo nível de comprometimento e de desempenho dos colegas homens. Assume, então, uma característica de frustração, cujos esforços desprendidos não levaram a resultado algum, exceto à derrota. Logo ser mulher no meio acadêmico, segundo essa axiologia central, seria uma desvantagem considerável.

Em articulação com a oposição ora descrita, identificamos duas outras que reforçam a estrutura significante básica da capa. $\mathbf{O}$ par igual $\mathbf{X}$ desigual coloca em dúvida uma pretensa condição equânime oferecida pelas instituições de pesquisa no que tange ao progresso de seus pesquisadores na carreira. Apesar de haver elementos comuns entre homens e mulheres ocupantes do posto (salário, encargos do trabalho...), o que existiria na prática é uma falta de consideração dos empregadores com as peculiaridades das pesquisadoras mulheres, que acumulam as funções sociais de mãe e de dona de casa e, por isso, acabariam sendo prejudicadas em sua carreira. Essa lacuna ficou mais bem evidenciada quando analisamos o texto descritivo da capa, em que o uso de palavras como "talvez" e "seja" indicariam uma situação mal resolvida, e cuja solução parece incerta ou distante.

$\mathrm{Na}$ verdade, a única opção vislumbrada para as pesquisadoras reverterem esse quadro desvantajoso é justamente seguir um percurso de negação de sua feminilidade (nãofeminino), o que representa na prática a postergação ou a renúncia de desejos comuns à maioria das mulheres, como casar e ter filhos. Assim, para conseguir evoluir em sua carreira acadêmica, a cientista deveria abrir mão de sua faceta feminina e assumir uma postura masculinizada, cada vez mais e focalizada no trabalho e, principalmente, competitiva. Ser feminina, portanto, é ir contra essa direção, isto é, torna-se sinônimo de frustração, de fracasso.

No texto em geral, podemos constatar que um valor perseguido nesse conjunto significante é o de igualdade, que rege as estruturas semionarrativas presentes na temática abordada na reportagem, capa e ilustrações. Em vez de ser algo inerente às relações humanas e, por sua vez, reger todos os indivíduos, vimos que, no caso em voga, o status padrão é o de desigualdade no que tange à condição social feminina. Trata-se de um valor que, por não estar instituído, necessita ser buscado e conquistado pelas mulheres para que elas tenham o 
mesmo reconhecimento dos homens, tanto nas relações socioprofissionais quanto nos direitos fundamentais de modo geral. É o que a História tem nos mostrado até então.

Portanto a busca feminina pela igualdade de direitos é um processo constante que tem apresentado resultados pontuais ao longo do tempo, especialmente no século passado - quando tais lutas ganharam dimensão, impacto e notoriedade (vide o Movimento Feminista e seus desdobramentos). Constituem-se de um conjunto de ações que visam a romper com um estado de continuidade presente nas relações sociais desde a Antiguidade - a desvalorização da mulher - e instituir novos parâmetros nas relações entre gêneros (descontinuidade). A ênfase nesse aspecto se justifica no percurso temporal presente nas ilustrações da reportagem, que ilustra claramente o caráter contínuo que envolve a luta da cientista em conseguir acompanhar o ritmo dos homens (a supervalorização masculina na sociedade), de modo a alcançar os mesmos resultados e, quem sabe, conseguir promover alguma mudança mais significativa nesse quadro (descontínuo). É uma luta que se arrasta por diversas fases da vida dela (da graduação à aposentadoria) e, como fica demonstrado, sempre em condições desvantajosas.

Ao tratarmos do percurso narrativo, convém mencionarmos que seu modelo é uma herança direta, ainda que mais aperfeiçoada e complexa, daquele utilizado por Propp em sua Morfologia do conto maravilhoso (1984). Nela, o folclorista russo organiza sua metodologia atendo-se às características formais dos contos populares russos, e deles extrai 31 mecanismos (chamados pelo autor de funções) que engendram e conferem sentido às narrativas em um caráter sucessivo. $\mathrm{O}$ sistema proppiano configura-se como uma teoria da ação, em que os elementos da narrativa estão sujeitos a sucessivas transformações - ainda que estabelecidas sob um prisma bastante rígido - e por meio das quais ela se constitui, revelando assim seu caráter dinâmico.

Essa dinâmica é dada por um conjunto de provas, que seriam elementos dinâmicos do conjunto da narrativa, que podem ser agrupadas nas 31 funções descritas por Propp (1984). Trata-se de elementos importantes para Greimas (1979) desenvolver o modelo actancial de sua teoria semiótica. A prova qualificadora equivale à competência do modelo greimasiano, é o momento no qual o destinador (força que orienta as ações da narrativa) atribui qualidades ao sujeito para que este seja capaz de realizar uma determinada tarefa. $\mathrm{O}$ exercício dessa competência (a performance) gera a transformação narrativa. A prova decisiva equivale à performance, isto é, quando o sujeito, dotado de determinadas competências, age de modo a gerar uma transformação, e tal ação pode ser bem-sucedida ou não. Por fim, a prova glorificadora equivale à sanção, isto é, a uma recompensa ou punição por parte do destinador ao sujeito conforme o resultado de sua performance.

No caso em tela, vemos que o sujeito da narrativa ilustrada na capa é a cientista, colocada em destaque tanto pelo texto descritivo quanto pelos elementos plásticos (cores, linhas, expressões), e cujo objeto-valor (elemento almejado) é o desenvolvimento na carreira profissional, demarcado aqui como a possibilidade de ela conseguir cargos mais elevados, prestigiados e rentáveis. Contudo há, em seu caminho, o homem, também cientista, que assume o papel de antissujeito ao perseguir o mesmo objeto-valor, os postos mais graduados na academia. Há, portanto, um querer-fazer que atua como mola propulsora do percurso narrativo tendo em vista a transformação dos sujeitos.

Nesse percurso, também acrescentamos outro ingrediente. Se, no caso do homem, o objeto-valor é o sucesso profissional, para a mulher o objetivo é bem mais complexo: buscar uma situação de equilíbrio entre a carreira acadêmica e a vida pessoal, já que a mulher assume um papel triplo (cientista + mãe + dona de casa), como demostrado na 
imagem figurativizada da cientista e de elementos que, metonimicamente, remetem a esses papéis sociais (jaleco/cientista + bebê/mãe + compras/dona de casa).

Para entrarem em conjunção com seus respectivos objetos-valor, entra em cena o destinador, figurativizado pela imagem do ambiente científico/universitário, que, em tese, garante a eles as mesmas condições de trabalho para que ambos apresentem desempenhos equivalentes. Isso se dá tanto no nível da manipulação, na condição de um dever-fazer (o cientista, na condição de empregado, deve apresentar uma produtividade compatível com o esperado pelo empregador) quanto no nível da competência, em que o local de trabalho daria a ambos os sujeitos os meios necessários para progredirem profissionalmente (na forma de um poder-fazer), restando apenas o desempenho individual de cada um.

Entretanto, apesar dessa aparente igualdade, que se reflete também na distribuição do contingente de cientistas por sexo (50\% para cada lado), isso não ocorre na prática, já que o homem aparece em inequívoca vantagem nesse contexto. Sem ter de se preocupar com os afazeres domésticos ou com os filhos - não no mesmo modo e medida que suas colegas mulheres -, os cientistas homens têm uma chance maior de crescer profissionalmente do que elas, já que estas precisam dedicar, com dificuldade, a mesma atenção ao trabalho, ao lar e à prole. Assim, embora a cientista se empenhe para cumprir seus compromissos (querer-fazer), ela não consegue atingir o mesmo desempenho dos homens ao ter de exercer simultaneamente três papéis sociais (não poder-fazer).

Em consequência disso, o homem é bem-sucedido em alcançar o objeto-valor, desempenhando plenamente sua performance (o sucesso na carreira), enquanto a mulher entra em disjunção ao tentar obtê-lo, pois, apesar de também receber os mesmos predicados, não consegue conciliar de forma adequada as duas demandas, sendo prejudicada em ambas. Mediante isso, o destinador (a academia) aplica uma sanção positiva ao homem, recompensando-o com postos mais altos na carreira universitária. Já a mulher, por não conseguir o mesmo desempenho, é sancionada negativamente e, por isso, fica sem a mesma oportunidade - amargando um "segundo lugar".

Enfim, um fenômeno importante e comum a esses textos atém-se a um aspecto subjacente ao nível narrativo do percurso gerativo de sentido: os predicados modais. Essas estruturas estão relacionadas às transformações que os enunciados de fazer e os de estado podem sofrer mediante a aquisição (ou não) de determinados valores. Esses valores podem estar ligados à ordem do querer, do dever, do saber, do poder e do crer - os quais se combinam com predicados do fazer e do ser. (GREIMAS; COURTÉS, 2008; BERTRAND, 2003; FIORIN, 2008).

No percurso narrativo em voga, além das modalidades do fazer já descritas, há igualmente a presença de um querer-ser dos sujeitos, em que essa modalidade representa uma busca pela conjunção com o objeto-valor (no caso, o mais pujante é o sucesso na carreira profissional) o qual é objeto de disputa entre homens e mulheres. Nesse mesmo percurso, também se institui outra modalidade, o dever-ser, caracterizado pela pressão de diversas esferas sociais (o empregador, a família, a sociedade...) para que os sujeitos obtenham o sucesso almejado e se tornem "vencedores", pesquisadores renomados e reconhecidos pelos pares e pela sociedade em geral. Contudo essas mesmas pressões oriundas dos diversos actantes envolvidos nesse cenário (e instituintes da modalidade do dever) também agem de maneira oposta, acarretando em um poder não-ser, em decorrência das limitações a que as mulheres estariam sujeitas em seu trabalho ao ter de conciliar um papel tríplice, não se dedicando detidamente a nenhum deles e, por isso, seriam prejudicadas ao buscar um status mais alto na carreira a despeito de seus esforços. 
Os predicados acima que engendram a narratividade de nosso objeto delineiam, com clareza, um elemento patêmico na relação entre actantes, sujeitos e objetos. $\mathrm{O}$ jogo existente entre o querer-ser e o poder não-ser é capaz de gerar no sujeito feminino uma série de grandezas relacionadas a um estágio de tensão, em virtude de a conjunção com um objetivo almejado não ser algo previsível ou certo, independentemente dos méritos da pesquisadora, algo que não acontece no sujeito masculino - ao contrário, este apresenta um percurso mais relaxado. E mais, tais predicados podem ser ainda reforçados ao se incluir a modalidade do saber, levando-se em conta todo o percurso do indivíduo na carreira e, devido ao conhecimento da instituição e dos meandros de seu meio, de seu conhecimento acerca das possibilidades de crescimento profissional.

Um estudo mais detido dos percursos de transformação dos sujeitos de estados e dos predicados modais que constituem tais relações abriu espaço para que a semiótica voltasse seu foco à análise das paixões no discurso, como empreendido por Greimas e Fontanille (1993). Existe nos discursos um componente patêmico que, até então, não havia sido considerado durante o desenvolvimento da teoria semiótica. Se, durante as primeiras décadas, a prioridade era explicar o "estado das coisas", mediante o percurso gerativo que desencadeava as transformações narrativas, os modos e os sujeitos do fazer, o foco no estudo das paixões está nas transformações dos "estados de alma", do ser dos sujeitos envolvidos no todo discursivo.

As paixões, sob a perspectiva da semiótica, não são analisadas sob um viés psicologizante, mas a partir dos efeitos de sentido presentes no texto que, de algum modo, modalizam os sujeitos de estado (ser). Elas derivam de diferentes combinações, sempre provisórias, de diferentes modalidades que afetem o ser do sujeito, e que são determinadas pela cultura. Um exemplo citado por Fiorin (2007, p. 10) é o da vergonha, estruturado pela combinação das modalidades querer-ser, não poder-não-ser e saber-não ser.

Ainda que o objeto em análise não permita uma configuração passional mais desenvolvida, em virtude de os sujeitos envolvidos assumirem uma faceta coletiva (isto é, são figurativizações de um determinado segmento socioprofissional, não apresentando uma identidade individualizada) e, portanto, tais configurações restringir-se-iam ao âmbito das potencialidades, cabem aqui algumas considerações. Retomando uma análise de Fiorin (2007) acerca das paixões no meio universitário, os elementos patêmicos acima descritos podem se desdobrar em uma série de outros percursos que podem assumir a face de paixões complexas - nas quais não está em jogo apenas uma expectativa de conjunção com um determinado objeto-valor, mas há uma espera fiduciária, segundo a qual o cientista busca essa conjunção e, mediante um contrato estabelecido com seu interlocutor (a instituição empregadora, ou melhor, o simulacro desta), acredita - ainda que sem certeza - que este irá lhe oferecer as condições necessárias para a realização de seu intento.

Uma relação como a descrita evidencia, essencialmente, estados de espera e de confiança, em que o sujeito visa a entrar em conjunção com um objeto qualquer de valor. $\mathrm{O}$ sujeito, baseado no querer-ser ou no crer-ser, coloca-se em estado de espera, querendo entrar em junção com o objeto visado. Por sua vez, estabelece um contrato com o seu outro e, portanto, firma uma relação fiduciária, ainda que isso não ocorra de modo consensual, apenas seja uma criação desse sujeito, ou melhor, um simulacro. A conjunção ou disjunção decorrente do percurso narrativo a se seguir é o fator gerativo dos estados passionais, sejam positivos (como a felicidade e o alívio) ou negativos (como a aflição e a infelicidade) (FIORIN; 2007; MELLO, 2005).

Contudo, diz Fiorin (2007), quando essa expectativa é frustrada, abre-se espaço para uma série de estados patêmicos decorrentes dessa disjunção, que podem variar de um 
sentimento de injustiça e seus desdobramentos (decepção, frustração, tristeza), mediante o não cumprimento desse contrato, até mesmo a sentimentos mais durativos - e, por isso, mais daninhos -, que exigem a reparação de uma perda (como o ressentimento e a vingança).

A descrição dessas potencialidades ajuda a entender o quanto o ambiente universitário, em que ainda vigora a ideia de se tratar de um cenário despessoalizado, sob a primazia de valores como a objetividade e a busca pela verdade, não está imune aos efeitos da paixão, na medida em que ela "é o móvel a impelir os seres humanos à ação, [logo] não pode estar ausente da vida acadêmica, não pode deixar de definir as relações do eu com a instituição em que vive, não pode estar ausente das relações sociais" (FIORIN, 2007, p. 13).

Por não estar imune às paixões, o ambiente acadêmico pode se converter em um cenário de tensões. Os contratos firmados entre cientistas e empregadores (formalizados ou situados no nível do simulacro) podem ou não ser cumpridos, desencadeando reações diversas. No caso em foco, esse contrato se resumiria em perspectivas equivalentes de trabalho e de desenvolvimento profissional para homens e mulheres. No entanto ocorre, na prática, uma depreciação ainda que sutil do trabalho feminino, pois as cientistas apresentam mais dificuldades para serem reconhecidas e, do mesmo modo, terem as mesmas oportunidades que os colegas homens. Tal fato, caracterizado pela frustração de uma expectativa, configurar-se-ia como uma violação do contrato e, portanto, uma quebra de confiança entre as instâncias, podendo suscitar dessa forma estados patêmicos negativos, de diferentes gradações (da apatia à revolta). São fatores que corroboram um clima de competitividade e individualismo exacerbados nas universidades, em detrimento de relações humanas mais saudáveis.

\section{AS ESTRUTURAS DISCURSIVAS}

Greimas (1979, p. 17) diz que na figuratividade, um dos elementos do nível discursivo, os deslocamentos dos objetos (as transferências, que dominam e dinamizam a lógica do nível narrativo), assim como qualquer ação praticada pelos sujeitos envolvidos na narrativa são recobertos por configurações discursivas variadas, que se desenvolvem de maneira figurativa. Não se trata de mera representação ou imitação do "real", mas de um processo que, segundo Bertrand (2003), se estrutura tanto na iconização, isto é, da proximidade das figuras com o mundo natural, quanto na abstração, em que há um distanciamento entre figura e mundo sensível - aqui, elas estariam associadas a conceitos, e não a entes concretos.

Pode-se perceber, à primeira vista, que a capa é fartamente figurativizada ao valer-se de elementos concretos, facilmente identificáveis e assimiláveis, e com isso construir um percurso temático coerente, cujo objetivo é mostrar ao leitor que o tema abordado é a desigualdade entre sexos na carreira acadêmica. A metáfora da corrida, que engloba todo o cenário retratado na capa, coloca em paralelo dois contextos diferentes (um ambiente esportivo e um ambiente profissional), mas que trazem um elemento comum: a competição. Se, no esporte, o atleta que reúne o maior conjunto de condicionantes favoráveis (boa saúde, infraestrutura, patrocínio) está mais apto a vencer uma disputa, o mesmo ocorre com o cientista, cujo sucesso na carreira acadêmica também dependerá de uma série de interveniências, tais como salários atrativos e oportunidades de desenvolvimento profissional.

Contudo esses elementos figurativos revelam que as condições a que os sujeitos estão submetidos não se equivalem. Enquanto o homem, na dianteira, corre com tranquilidade e consegue aproximar-se da linha de chegada - elemento que figurativiza, por metáfora, o sucesso na carreira acadêmica -, a mulher se vê às voltas com o fato de, além de 
ter de alcançar seu rival, precisa tomar cuidado para não derrubar o balão volumétrico em suas mãos, nem o pacote de compras e/ou o bebê que ela carrega em cada um dos braços.

No que tange à diversidade de elementos figurativos, nota-se que a mulher, figura de destaque na peça, está recoberta por uma série deles, a começar pelos itens que permitem defini-la como uma pesquisadora ligada ao meio acadêmico - o balão volumétrico, os óculos e o jaleco. Desses elementos, destacamos o primeiro e o segundo pelos motivos a seguir.

O primeiro elemento, o balão volumétrico, é portado pelos dois sujeitos. Esse objeto não apenas figurativiza por metonímia (todo pela parte) o ofício de cada um, mas atua como um elemento fundamental na corrida, algo que não pode ser derrubado ou perdido. Seria mais do que uma representação figurativa da função que ocupa, seria toda a sua trajetória como cientista. Assim, ao chegar à frente na disputa, o homem conseguiu levar a sua carreira ao ápice, alcançando os postos mais prestigiados. Já a mulher, logo atrás, não tem a mesma chance e, assim, não consegue progredir profissionalmente.

O segundo elemento, os óculos, atua em uma direção semelhante ao figurativizar, também por metonímia, o cientista e o trabalho acadêmico. Na capa, o acessório escapa da face da mulher como consequência do efeito da velocidade do adversário. Esse movimento figurativiza uma condição de desvantagem da mulher nessa relação competitiva: além de ser superada pelo colega homem no que tange à carreira, a cientista mulher, ao perder os óculos, fica desnorteada, perde o rumo de seu desempenho profissional e se prejudica ainda mais em seu ofício. Essa sensação de desorientação se deve também em função de seu papel triplo, já mencionado há pouco, que a impede de se dedicar exclusivamente à profissão em virtude de aspectos da vida pessoal (o lar e os filhos) que precisam ser igualmente atendidos.

Não podemos deixar de mencionar que os próprios sujeitos da capa, assim como de toda a reportagem, são figurativizações, ao incorporarem (também por metonímia) os predicados pertinentes de uma classe profissional em particular, cada um representando um sexo, e assumem, no nível discursivo, a condição de atores. No aspecto eminentemente figurativo, a classe de mulheres cientistas, iconizada pela mulher na capa, encontra-se em franca desvantagem no desenvolvimento profissional em relação aos colegas do sexo masculino, iconizados pelo homem, apesar das condições de trabalho apontarem para um aparente equilíbrio - tanto no contingente de profissionais por sexo, quanto nas oportunidades dadas pela academia - que não é confirmado na prática.

Com relação ao texto escrito, também cabem algumas considerações. A semiótica entende que tanto o discurso do jornalismo quanto o da ciência compartilham a característica de transmitir ao leitor uma impressão de verdade, já que lidam com saberes que tanto se destinam a relatar e descrever os acontecimentos do mundo (jornalismo) quanto relatar e descrever aspectos do funcionamento dos fenômenos naturais e humanos circundantes em nosso mundo (ciência). Isso depende de uma relação de veridicção, estipulada mediante um contrato entre enunciador (emanador do discurso) e enunciatário (público-alvo) de que seus dizeres são verdadeiros ou, no mínimo, aproximam-se da verdade.

Em termos semióticos, como o faz Greimas (1981), o enunciador apresenta-se como portador de um fazer-saber, uma competência que visa a legitimá-lo perante seu enunciatário como alguém que transmite uma informação verdadeira e que, além disso, também assume um dever-fazer, apresentando-se como um ente comprometido com seu público, valendo-se de fontes confiáveis e respeitando critérios profissionais e éticos no exercício de seu trabalho. Para isso, visa a convencer esse receptor, por meio de um quererfazer e um fazer-crer, de que possui esses atributos, utilizando os meios necessários para atingir tal objetivo. 
No entanto, ao lermos o texto descritivo da capa analisada, vemos um elemento que, a princípio, parece destoar do contrato veridictório do qual tratamos acima. Se um leitor procura se informar em uma revista científica, está em busca de um mínimo de certezas para saciar as próprias indagações a respeito de um assunto qualquer. Mas o uso do advérbio "talvez" e do verbo "ser" no subjuntivo no texto em destaque ("Para mudar esse quadro talvez seja preciso alterar a dinâmica da academia") lançam no enunciado uma dado de incerteza. Logo o leitor poderia estranhar ao ver, no mesmo enunciado, o prelúdio de uma solução para o problema relatado ("Para mudar esse quadro...") e não encontrá-la, mas apenas uma saída possível; com isso, suas indagações não seriam sanadas, mas ampliadas.

Apesar desse indicativo de dúvida gerar estranhamento ("talvez seja preciso"), ele é justificável. Essa estratégia mostraria ao leitor não uma situação de descuido ou negligência, mas revelaria as dificuldades dos próprios cientistas em buscar uma solução para o caso, de modo que pesquisadores e pesquisadoras possam usufruir, de modo equivalente, das mesmas condições para se desenvolverem profissionalmente e preservar a vida pessoal. Além de a comunidade científica não dispor de uma solução definitiva para esse impasse, os jornalistas também não a possuem, apenas deixam evidente essa lacuna a ser resolvida.

Vale dizer que essas expressões de incerteza também permeiam o texto principal e são corroboradas especialmente por depoimentos de pesquisadoras (NOGUEIRA, 2011, p. 25) que são favoráveis a uma maior flexibilidade do trabalho feminino, de maneira que elas consigam administrar a vida pessoal e a profissional com mais tranquilidade. São depoimentos que expressam desejos de mudança, mas não há neles sinais concretos que apontem para uma mudança radical desse quadro - o que se vê é uma transformação gradual, mas ainda marcada por algumas incertezas e um certo ceticismo.

"Acho que temos de repensar a maneira como se trabalha na universidade. Muitas vezes, nos cargos mais altos, espera-se que a pessoa tenha uma disponibilidade que é incompatível com o que a maioria das mulheres quer para sua vida. Será mesmo necessário que um reitor enfrente jornadas de 13 horas de trabalho?", questiona Léa.

"O que precisa mudar é o senso comum", argumenta Luci. "É ele que enxerga algumas profissões como masculinas e outras como femininas, que estabelece como missão da mulher cuidar da casa e da prole, que faz com que a mulher enfrente dificuldades para ser julgada competente para ocupar posições de poder. Essas iniciativas apenas irão amenizar as faltas".

A figuratividade presente na capa repercute em toda a composição gráfica da reportagem, inclusive no estilo e no traço. A metáfora da corrida, a qual ilustra a competitividade entre homens e mulheres no meio acadêmico, perpassa pelas oito páginas do texto principal. Os personagens da capa, que metonimicamente representam os indivíduos da classe científica conforme cada gênero (o cientista e a cientista), iniciam a "corrida" logo após as suas respectivas formaturas (NOGUEIRA, 2011, p. 18), sob os olhares orgulhosos de seus familiares - como deixam patentes as imagens de fundo, em que aparecem as figuras das famílias dos recém-formados. Mesmo tendo concluído a graduação, os jovens aspirantes à carreira científica convivem precocemente com uma tensão pelo seu êxito profissional e com as pressões oriundas dos diversos contextos a que estão sujeitos - profissional, social, familiar.

O aspecto temporal dessa narrativa contada pelas ilustrações não apenas reitera a temática principal da reportagem, mas torna facilmente compreensível os diferentes estágios 
pelos quais os personagens irão passar ao longo de sua "maratona" e, gradualmente, o caráter de desigualdade que vai se delineando conforme o passar dos anos. Se, quando formados, homem e mulher "largam" juntos, significa que ambos, nesse momento, desfrutam de condições aparentemente análogas de competitividade e, teoricamente, deveriam usufruir das mesmas chances e oportunidades de desenvolvimento profissional.

Não é o que ocorre, entretanto, na prática. O percurso acadêmico das mulheres, logo no início, tem sido historicamente marcado por dificuldades adicionais, não inerentes aos méritos próprios. Isso fica patente na reportagem (NOGUEIRA, 2011), ao se retomar a história da física polonesa Marie Curie, que a despeito de suas relevantes descobertas no campo da radioatividade - que lhe renderiam o Prêmio Nobel anos depois - e de seus progressos como cientista, ela sofreria as amarguras dos costumes e preconceitos da época, em que o fato de uma mulher alcançar tamanhos feitos era minimizado - ou mesmo condenado - pela sociedade machista de então, a ponto de a cientista ser creditada, em um dos seus trabalhos, como "assistente" do marido (o físico francês Pierre Curie).

Se naquela época (início do século XX) o comportamento machista da sociedade era um fator compreensível, entre outros, para explicar a fraca penetração das mulheres no mercado de trabalho de modo geral, o que se vê hoje é a manutenção de determinados estereótipos que, de algum modo, inibem uma presença feminina mais expressiva no meio acadêmico (apesar de haver certo equilíbrio no preenchimento geral de vagas por homens e mulheres), ou então fomentam a criação de obstáculos que dificultam as mulheres de se destacar nesse segmento, sobretudo nas chamadas "ciências duras" (ciências exatas e engenharias). Argumentos (não comprovados) como os que as mulheres teriam menos aptidão do que os homens no raciocínio matemático, ou mesmo o fato de que elas deveriam se dedicar mais à criação dos filhos do que ao trabalho (tal como antigamente) endossam um percurso disforizante, pelo qual passam as mulheres ao longo de suas carreiras - apesar de seus méritos como cientistas -, que se converte em uma série de empecilhos ao longo dessa trajetória (NOGUEIRA, 2011).

A disforia da qual falamos já começa a se evidenciar nas páginas seguintes ( $\mathrm{p}$. 20, 22, 23 e 25), em que a mulher começa a ficar em desvantagem quando comparada ao seu colega do sexo masculino. Na página 20, vemos uma nítida diferença no ritmo e na velocidade de ambos, em que o homem corre de maneira mais vigorosa, enquanto a mulher demonstra maior lentidão e mesmo uma certa apatia. Essa diferença se mantém nos estágios seguintes, em que aparecem em cena outros elementos figurativos pertinentes à família - no caso, esposa e filhos para o homem e, para a mulher, um bebê nos braços.

A maternidade, nessa cena, constitui-se outro elemento disforizante do sujeito feminino de forma semelhante ao que é mostrado na capa dessa edição de Unesp Ciência. O sujeito masculino consegue manter a dianteira na "maratona" tendo em vista o apoio da esposa, que se dedica à criação do filho, enquanto desenvolve normalmente seu trabalho na academia. Já a mulher não dispõe desse apoio e tem de levar o filho consigo na caminhada, fazendo-a perder foco e velocidade na "corrida". Essas figuras endossam a relação já estabelecida no nível discursivo, em que o bebê da cientista figurativiza o fato de ela ter que dividir suas atenções e energias entre o trabalho e a criação dos filhos (diferentemente dos colegas homens), prejudicando-a em seu desenvolvimento profissional.

Nas últimas imagens, o cenário acadêmico e a metáfora criada na narrativa se aproximam aos desenhos, ao fundo, de ilustres cientistas da História (Albert Einstein, Stephen Hawking, Charles Darwin, Marie Curie e, ao final, Alfred Nobel, representado da mesma forma como na medalha do prêmio homônimo). A "maratona" rumo ao sucesso na carreira científica é posta em paralelo com a trajetória desses grandes pesquisadores, até que 
se chegue ao clímax - a linha de chegada, ou melhor, a um nível de realização comparável à conquista do Prêmio Nobel, considerado o ápice da carreira de um pesquisador. Entretanto, enquanto o homem mantém seu ritmo vigoroso, a despeito da ação do tempo nos sujeitos presente desde o início, a mulher precisa transpor uma série de "barreiras" para conseguir chegar ao mesmo objetivo. As barreiras presentes na pista, análogas às vistas nas competições esportivas congêneres, figurativizam as várias dificuldades enfrentadas pelas cientistas em seu percurso profissional, muitos deles já apresentados em nosso trabalho - preconceitos, estereótipos, subvalorização, dificuldades em conciliar as vidas profissional e pessoal, enfim, só para citar os mais relevantes.

Por fim, é importante relatarmos uma preocupação do enunciador em colocar a instituição de ensino (Unesp) em posição de destaque nesse relato. Mesmo que se reconheça o cenário ainda desigual no meio científico, é ressaltado que a instituição dá um passo importante na contramão dessa lógica ao nomear quatro professoras da Universidade como pró-reitoras, isto é, como integrantes da cúpula institucional (somente abaixo do reitor e do vice-reitor). Há um destaque dessa informação logo no início da reportagem e também próximo ao final, com um depoimento da pró-reitora de pesquisa da Unesp.

Se hoje sua [das mulheres] presença na academia, na pesquisa e nas instituições científicas não espanta ninguém (na Unesp, por exemplo, mulheres ocupam quatro das cinco pró-reitorias), isso não significa que os obstáculos e dificuldades relacionados às diferenças de gênero tenham sido completamente aplainados (NOGUEIRA, 2011, p. 19).

E a presença de mulheres nos postos de comando pode acabar tendo um efeito multiplicador. É o que pensa Maria José Giannini, pró-reitora de Pesquisa da Unesp. "A escolha de quatro mulheres para as pró-reitorias [da Universidade] foi um ato de ousadia. Acho que isso é importante principalmente para quem está ingressando na academia. Talvez elas já encontrem menos problemas do que nós tenhamos enfrentado para galgar a carreira." (NOGUEIRA, 2011, p. 25).

O "ato de ousadia" a que a pró-reitora se refere coaduna com a ideia de descontinuidade da qual falamos no início da análise, ou seja, de romper com a lógica de continuidade que perdura na sociedade de modo geral, segundo a qual as mulheres ainda são subvalorizadas e discriminadas no meio profissional, apesar dos recentes avanços nesse sentido. A Unesp, nesse contexto, seria alçada a uma posição de vanguarda por nomear pesquisadoras para cargos do alto escalão e, com isso, marcar contraposição frente a esse discurso em vigor. Trata-se de constatações, portanto, que buscam fortalecer a imagem institucional da Universidade, colocando-a como uma entidade que valoriza suas profissionais e não enxerga empecilhos ao colocá-las em postos estratégicos, ainda que tal iniciativa se destaque por se configurar como uma exceção à regra geral, em vez de serem ressaltados os eventuais méritos das dirigentes.

\section{EXPRESSÃO E CONTEÚDO: RELAÇÕES SEMISSIMBÓLICAS}

Nesta última parte, nosso foco será analisar os elementos constituintes do plano da expressão, conforme os trabalhos de Floch (1985) e Pietroforte (2004; 2011). Se, durante o seu desenvolvimento, a semiótica elaborou um modelo teórico suficientemente complexo e abrangente que contempla uma série de aspectos pertinentes ao conteúdo, o 
próximo passo para aprimorar o modelo seria articular ambos os planos a partir da relação entre categorias da expressão e do conteúdo, ou melhor, de relações semissimbólicas.

Pietroforte (2004), ao retomar os estudos de Floch (1985), descreve o semissimbolismo como uma condição intermediária, situada entre a arbitrariedade do signo, como preconizava Saussure (2006), e a motivação do símbolo, por se tratar de uma relação direta entre os dois planos da linguagem. Com o intuito de aplicar a teoria semiótica no estudo das linguagens plásticas, Floch desenvolve três categorias concernentes ao plano da expressão: cromática, relativa às cores; topológica, que diz respeito à organização espacial dos elementos; e eidética, às formas dos elementos constituintes da figura plástica. Essas categorias guardam semelhança com aquelas presentes no plano do conteúdo.

Voltando ao objeto de análise, detectamos no plano de expressão elementos plásticos que se conformam com essa axiologia central do plano do conteúdo (feminino $\mathrm{X}$ masculino). Na categoria cromática e na eidética, percebemos que a ilustração da pesquisadora tem várias cores, contraste, brilho, além de ser retratada integralmente (sem cortes), isto é, apresenta um alto nível de detalhamento que confere à figura uma posição de destaque no conjunto da capa. A imagem do homem, ao contrário, é retratada em tom sépia, com poucos detalhes (menos contraste e brilho) e apenas a metade inferior de seu rosto é mostrada - impedindo uma identificação mais precisa de sua fisionomia. O único (mas importante) elemento de destaque para o homem ocorre no nível topológico da capa, por ocupar um espaço maior que o da mulher e sendo posto à direita. A mulher, à esquerda, mesmo valorizada cromaticamente, recebe um investimento semântico de desvalorização no conjunto da capa.

\begin{tabular}{|c|c|}
\hline Plano do Conteúdo & Feminino X Masculino \\
\hline Plano da Expressão & $\begin{array}{c}\text { Policromia X Monocromia } \\
\text { Esquerda X Direita }\end{array}$ \\
\hline
\end{tabular}

Quadro 1 - Axiologias presentes nos planos de expressão e conteúdo na capa de Unesp Ciência.

Pelo cotejamento das axiologias dos dois planos, tendo em vista sua articulação e homologação, detectamos uma relação contrastiva entre as categorias cromática e eidética com as oposições do plano de conteúdo. Se, no material plástico, a figura da pesquisadora é valorada pela variedade de cores e pelo nível de detalhamento em suas formas (o que denotaria, a princípio, uma relação eufórica), o mesmo não ocorre no plano de conteúdo, em que a cientista é depreciada por valores disfóricos - frustração e discriminação. Somente há conformidade das axiologias do conteúdo com a oposição revelada pela categoria topológica, que coloca a mulher em posição de desvantagem - e, portanto, disfórica.

O contraste criado por esse jogo valorativo de expressão e conteúdo é que intensifica as relações de sentido engendradas na capa. $\mathrm{O}$ destaque dado à figura feminina pelos elementos imagéticos não tem por objetivo realçar seus aspectos positivos, mas, ao contrário, evidenciar justamente os valores negativos. É desnudar, por meio da imagem de capa, as condições desiguais de trabalho a que são submetidas as mulheres cientistas, já que, pelo fato de suas peculiaridades físicas, psicológicas e sociais não serem levadas em consideração pela academia, elas são prejudicadas profissionalmente em relação aos seus colegas homens por não serem, em tese, tão competitivas quanto eles.

Outro elemento importante para destacar essa temática é minimizar o impacto da figura masculina no conjunto da capa, procedimento esse que consistiu em duas etapas. A primeira, no âmbito plástico, foi simplificar o desenho do cientista tanto nos detalhes quanto 
nas cores (monocromático) e nas formas (rosto aparece pela metade). A segunda manifesta-se no texto descritivo, já que não há nele nenhuma referência explícita aos pesquisadores. $\mathrm{O}$ texto toma como único referencial a mulher, que exerce o papel de sujeito dos dois primeiros períodos, ainda que com sentido passivo pelos verbos de ligação ("Mulheres já são metade dos pesquisadores, mas continuam minoria nos altos postos"). Isso demonstraria a duratividade desses processos e o fato de que eventuais mudanças nesse quadro demandarão tempo significativo para se efetivarem.

Logo a estratégia dessa capa foi o de valorizar a figura feminina para realçar as condições de desigualdade profissional vivenciadas pelas mulheres no contexto acadêmico, apesar de elas ocuparem metade dos cargos de pesquisador no Brasil, pois esse elemento se configura como o fato principal da reportagem vinculada à capa e, portanto, merece ser destacado. A figura masculina, por sua vez, exerce, nesse contexto, um papel complementar na construção dos sentidos da peça, pois não é novidade o fato de os homens ocuparem a maior parte dos altos cargos no mercado de trabalho brasileiro - são evidências de uma cultura machista ainda muito forte no país.

Agora, vamos nos ater às relações semissimbólicas das ilustrações internas. Podemos ver que a homologação das relações entre expressão e conteúdo é mantida nos desenhos que ilustram a reportagem de capa, além de acrescidas de outros elementos. A relação de policromia $\mathbf{X}$ monocromia existente entre os atores da narrativa permanece, assim como a topologia desses elementos (mulher à esquerda e homem à direita). A reiteração dessas configurações, portanto, estabelece uma continuidade entre os conjuntos significantes capa e reportagem, e, da mesma forma, o destaque dado à figura da cientista mulher evidencia, como acontece na capa, a valorização dada pelo enunciador por essa figura - ainda que isso seja para destacar a posição disfórica desta última no texto.

Outras categorias axiológicas do plano de expressão são perceptíveis e homologáveis ao par feminino $\mathbf{X}$ masculino, existente no plano de conteúdo. A primeira delas guarda relação estreita com uma informação divulgada pela reportagem, que diz que a participação feminina na academia é majoritária nas áreas de ciências humanas, saúde, letras e artes; contudo, os homens são maioria nas engenharias e nas áreas de ciências exatas e agrárias.

Essa constatação, baseada em dados do Conselho Nacional de Desenvolvimento Científico e Tecnológico $(\mathrm{CNPq})$, corrobora uma visão eufórica das chamadas hard sciences no mundo acadêmico, culturalmente mais prestigiadas tanto em status quanto em penetração no meio científico - especialmente no que tange à produção científica e à obtenção de financiamentos para pesquisa, mais facilitada e abundante para os pesquisadores dessas áreas. Em contrapartida, as ciências humanas gozam de uma condição oposta - subvalorizada, depreciada e com margens mais estreitas de desenvolvimento se comparada à área de ciências exatas. Portanto vemos aqui uma euforização discursiva das ciências "duras" e uma disforização das ciências humanas (e algumas da área de saúde) de modo geral.

Nas ilustrações da reportagem, mais destacadamente na página 20, vemos que a parte alta do plano de fundo apresenta uma tonalidade fria (azul, verde ou uma mistura de ambas) e, no mesmo nível, vemos figuras que remetem metonimicamente ao campo das ciências exatas, como representações de átomos e de moléculas, além da letra grega $\pi(\mathrm{Pi})$. No plano inferior, as cores são quentes, pendendo para o vermelho ou laranja, e no mesmo nível aparecem outros elementos figurativos a campos como o da Psicologia (letra grega $\psi-$ Psi), da Enfermagem (lâmpada, cruz e cobra) e das Ciências da Linguagem ou da Comunicação (máquina de escrever). Assim, podemos constatar que as categorias cromáticas e topológicas 
do plano de expressão homologam a axiologia central do plano conteúdo, em que as hard sciences recebem um tratamento eufórico, enquanto áreas como a Psicologia, as Letras e outras (as ciências humanas em geral) são disforizadas.

\begin{tabular}{|c|c|}
\hline Plano do Conteúdo & Feminino X Masculino \\
\hline \multirow{3}{*}{ Plano da Expressão } & Policromia X Monocromia \\
& Esquerda X Direita \\
& Baixo X Alto \\
& Cores quentes X Cores frias \\
\hline
\end{tabular}

Quadro 2 - Axiologias presentes nos planos de expressão e conteúdo na reportagem de capa de Unesp Ciência.

Nos infográficos, verificamos também a convergência cromática com as axiologias descritas, pois as mulheres são representadas pela cor vermelha (quente, disfórica), enquanto se usa o azul (fria, eufórica) para os homens. Esse procedimento, além de garantir maior padronização e coerência entre os elementos da peça informativa, reitera a homologação entre os valores de expressão e de conteúdo homologados pelas relações semissimbólicas.

Por fim, podemos dizer que as relações entre expressão e conteúdo evidenciam um percurso semionarrativo e discursivo disfórico para as mulheres na ciência, já que, além da desvalorização de seu trabalho em decorrência de estereótipos e preconceitos de gênero ainda não superados plenamente, elas também ficam em desvantagem em virtude de a maioria delas escolher áreas de atuação que, de acordo com o conjunto significante, também são subvalorizadas em comparação com as áreas do conhecimento predominantemente masculinas. Assim, a condição de desvantagem feminina no mercado de trabalho é amplificada pelo conjunto do texto, o que torna a temática ainda mais relevante e, também, atrativa para o leitor - inclusive o potencial.

\section{CONSIDERAÇÕES FINAIS}

Ao longo deste artigo, procuramos mostrar as relações de sentido construídas na capa e na reportagem principal da edição 17 da revista Unesp Ciência, desde seus elementos mais abstratos e profundos até aqueles mais superficiais e complexos, levando-se em consideração tanto a forma desse conteúdo - como relatado pelo percurso gerativo de sentido - quanto pelos seus elementos plásticos, que se articulam entre si e engendram uma rede de relações significantes.

Também pudemos verificar o quanto os recursos expressivos utilizados pelas mídias informativas não exercem meramente um papel estético, mas visam a chamar a atenção dos potenciais leitores e estabelecer o quanto antes um contrato, regulado por modalidades veridictórias baseadas na expectativa de o leitor encontrar no periódico determinados conteúdos que satisfaçam suas necessidades de consumo de informação, enquanto o produto midiático se oferece como o objeto capaz de saná-las.

Assim, uma temática complexa e atual como a retratada pela reportagem de capa é figurativizada e articulada de maneira a arrebatar mais facilmente o enunciatário com vistas a motivá-lo a continuar a leitura (ou seja, a comprar a revista), valendo-se de elementos mais concernentes com o repertório cognitivo-cultural médio do público-alvo, tal como retratar a desigualdade entre homens e mulheres no meio acadêmico sob a metáfora de uma competição esportiva. $\mathrm{O}$ conjunto complexo de valores, relações lógicas e figuras pertinentes 
à temática abordada na capa de Unesp Ciência tornou-se, desse modo, um objeto atraente e palatável, mais suscetível a ser consumida. As imagens internas da revista que compuseram a reportagem vão ao encontro desses princípios, ajudando a constituir um todo de significação que cative seu público-alvo.

\section{REFERÊNCIAS}

BERTRAND, D. Caminhos da semiótica literária. Bauru: Edusc, 2003.

BUENO, W. C. Jornalismo científico: revisitando o conceito. In: VICTOR, C.; CALDAS, G.; BORTOLIERO, S. (Orgs.). Jornalismo científico e desenvolvimento sustentável. São Paulo: All Print, 2009. p. 157-178.

Jornalismo científico: resgate de uma trajetória. Comunicação \& Sociedade, São Bernardo do Campo, n. 30, p. 209-220, 1998.

FIORIN, J. L. Semiótica das paixões: o ressentimento. Alfa, São Paulo, v. 51, n. 1, p. 9-22, 2007.

Em busca do sentido: estudos discursivos. São Paulo: Contexto, 2008.

FLOCH, J. M. Petites mythologies de l'œil et de l'esprit: pour une sémiotique plastique. Paris: Hàdes; Amsterdam: Benjamins, 1985.

GREIMAS, A. J. As aquisições e os projetos. In: COURTÉS, J. Introdução à semiótica narrativa e discursiva. Coimbra: Almedina, 1979. (Prefácio).

Semiótica e ciências sociais. São Paulo: Cultrix, 1981.

.; FONTANILlE, J. Semiótica das paixões: dos estados de coisas aos estados de alma. São Paulo: Ática, 1993.

.; COURTÉS, J. Dicionário de semiótica. São Paulo: Contexto: 2008.

HERNANDES, N. A mídia e seus truques: o que jornal, revista, TV, rádio e internet fazem para captar e manter a atenção do público. 2. ed. São Paulo: Contexto, 2012.

HJELMSLEV, L. Prolegômenos a uma teoria da linguagem. São Paulo: Perspectiva, 1975.

LARA, G. M. P.; MATTE, A. C. F. Ensaios de semiótica: aprendendo com o texto. Rio de Janeiro: Nova Fronteira, 2009.

LEIBRUDER, A. P. O discurso de divulgação científica. In: BRANDÃO, H. H. N. Gêneros do discurso na escola. 2. ed. São Paulo: Cortez, 2001. p. 229-269.

MELLO, L. C. M. F. Sobre a semiótica das paixões. Signum: Estudos Linguísticos, Londrina, n. 8/2, p. 47-64, dez. 2005.

NOGUEIRA, P. A ciência das mulheres. Unesp Ciência, São Paulo, n. 17, p. 18-25, mar. 2011.

ORLANDI, E. P. Divulgação científica e efeito leitor: uma política social urbana. In: GUIMARÃES, E. (Org.). Produção e circulação de conhecimento: Estado, mídia, sociedade. Campinas: Pontes/NJC-Unicamp, 2001. p. 21-30.

PIETROFORTE, A. V. Semiótica visual: os percursos do olhar. São Paulo: Contexto, 2004.

Análise do texto visual: a construção da imagem. 2. ed. São Paulo: Contexto, 2011.

PROPP, V. I. Morfologia do conto maravilhoso. Rio de Janeiro: Forense Universitária, 1984.

SAUSSURE, F. Curso de linguística geral. 27. ed. São Paulo: Cultrix, 2006.

ZAMBONI, L. M. S. Heterogeneidade e subjetividade no discurso da divulgação científica. 1997. Tese (Doutorado em Linguística) - Instituto de Estudos da Linguagem, Universidade Estadual de Campinas, Campinas.

Recebido em: 04.03.13

Aprovado em: 04.06.13

Disponível em: http://seer.fclar.unesp.br/casa 


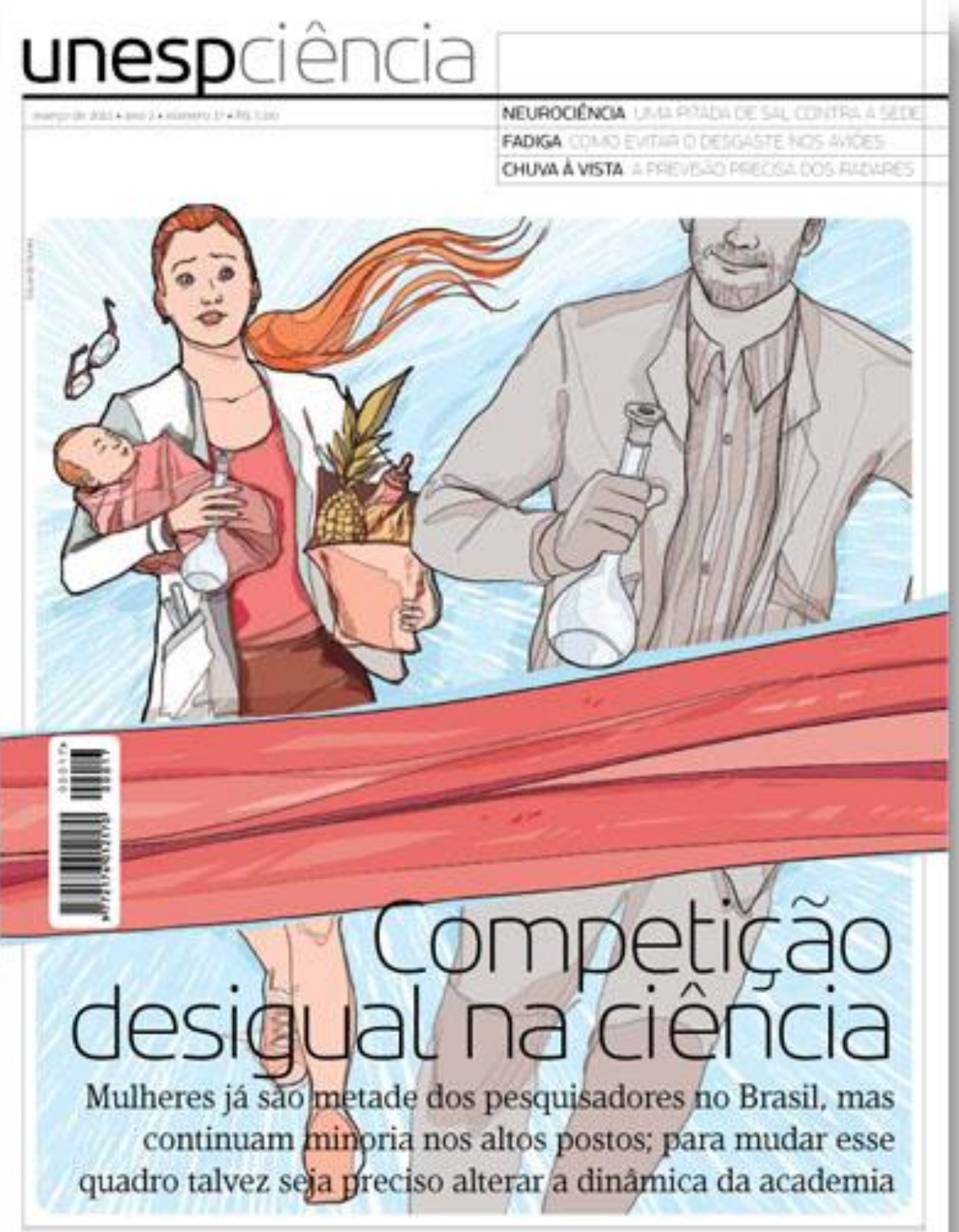



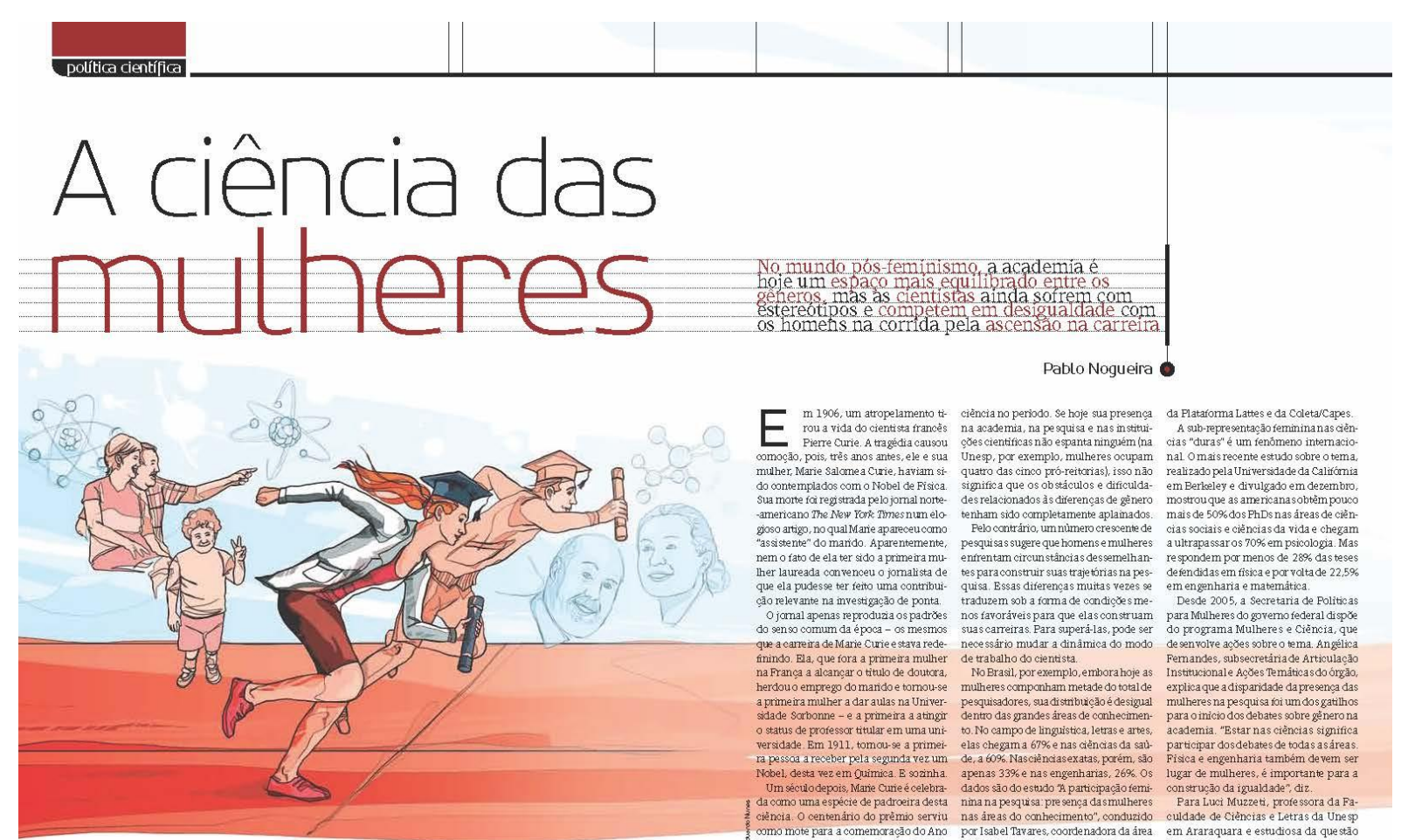

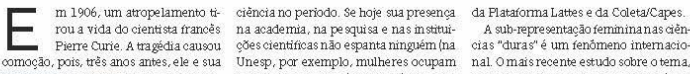

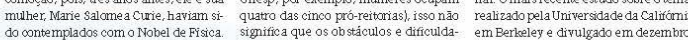

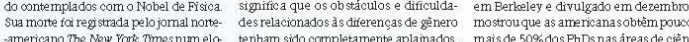

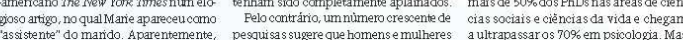

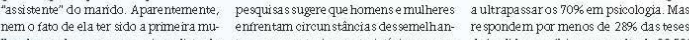

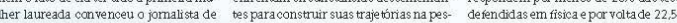

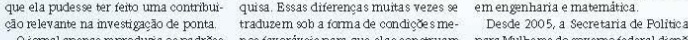

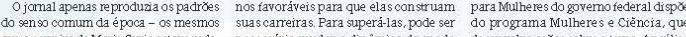

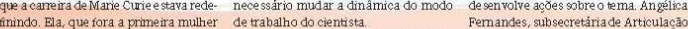

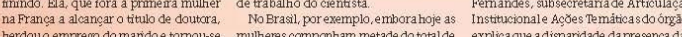

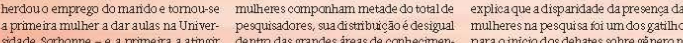
thes, academia. "Estar nas ciências signifif

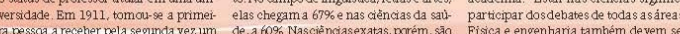

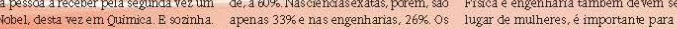

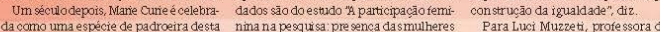

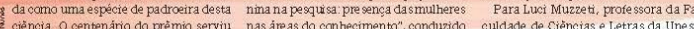

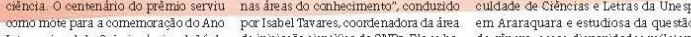

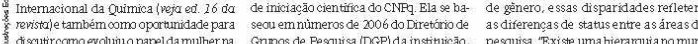

1

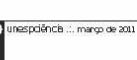

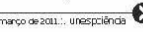

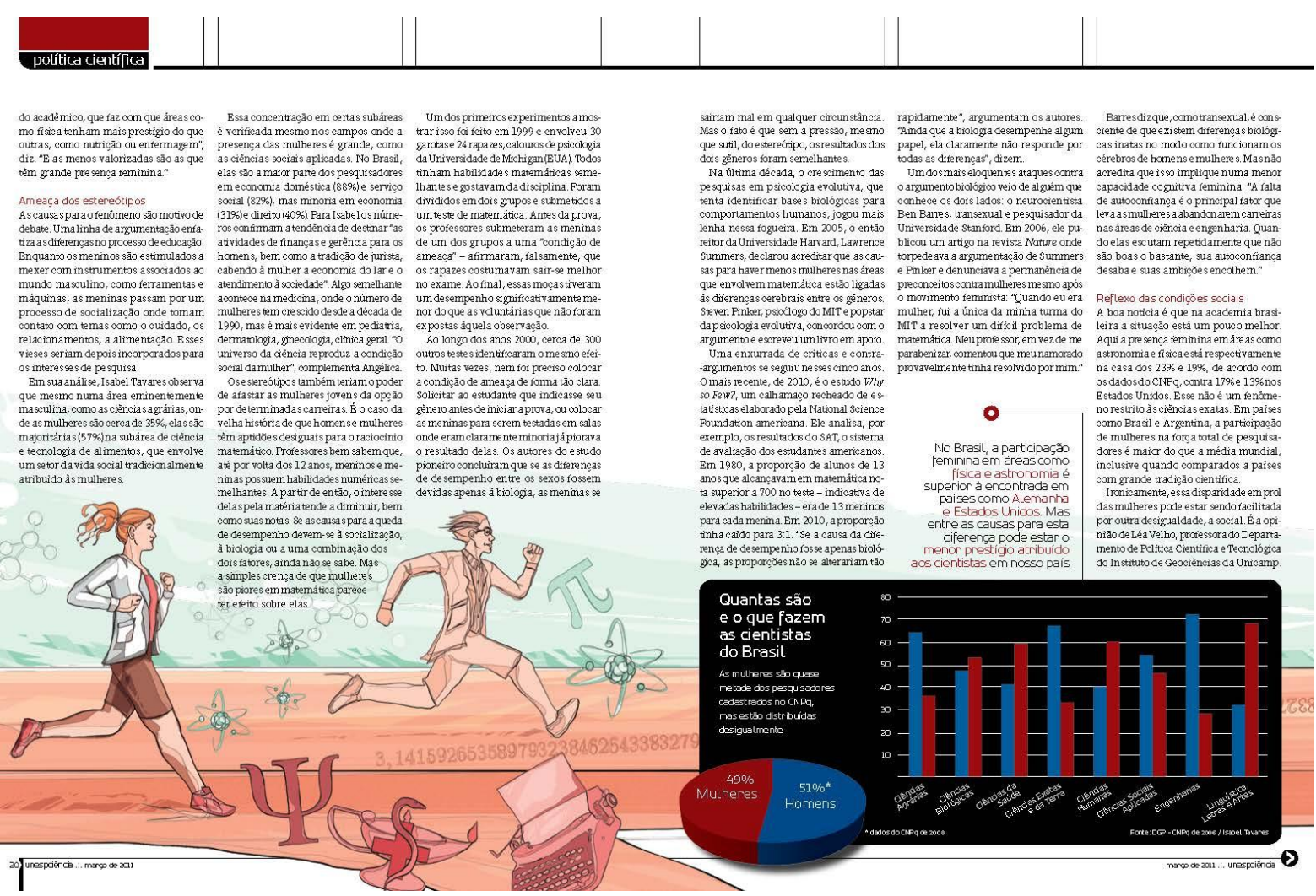

Disponível em: http://seer.fclar.unesp.br/casa 
CASA, Vol.11 n.1, julho de 2013
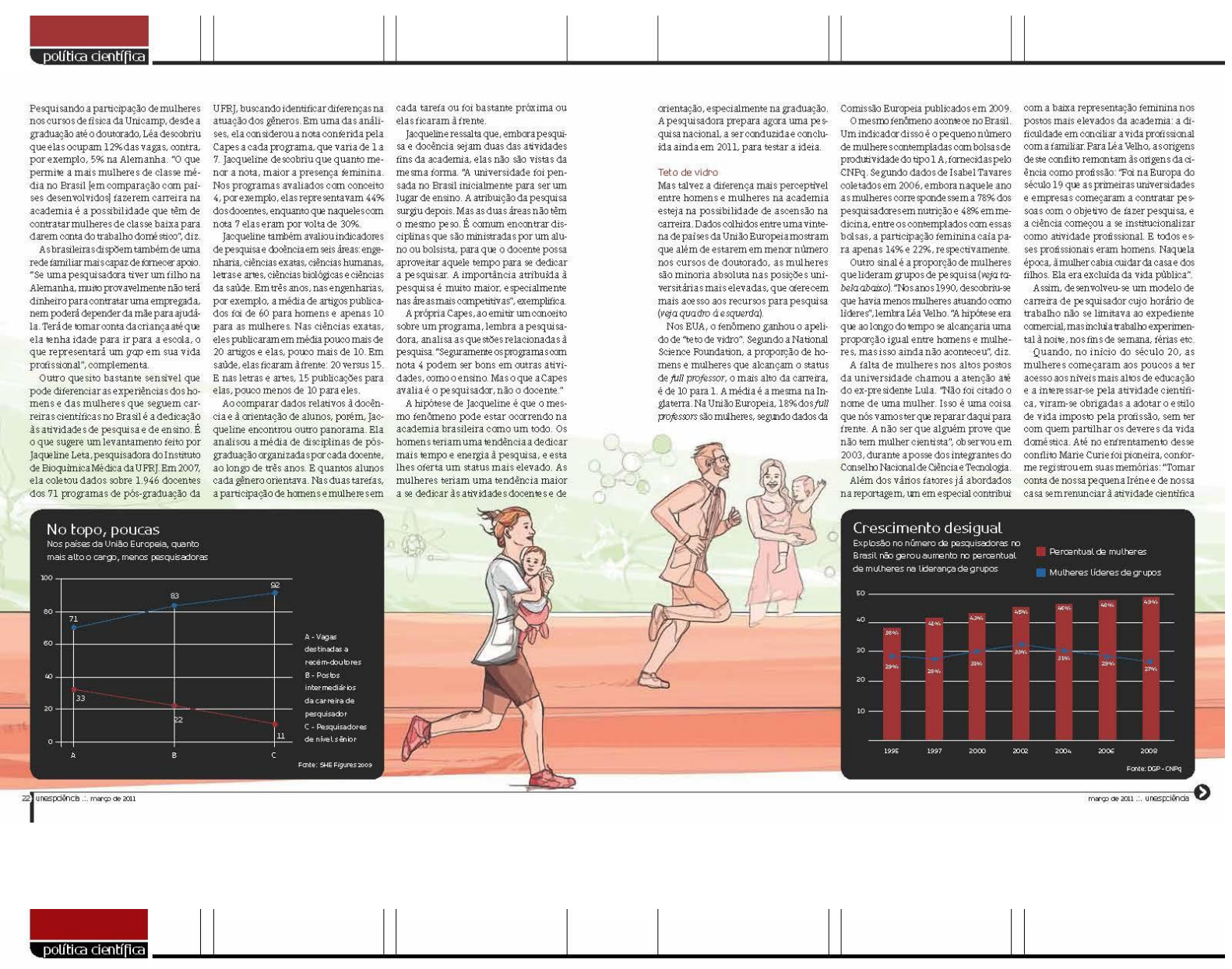

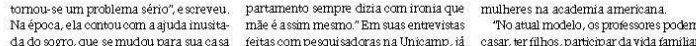

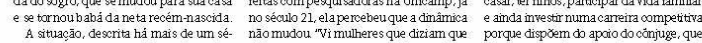
culva aind o

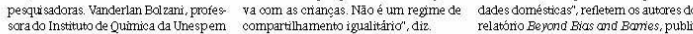
Araraquara e primeira mulher apresidira

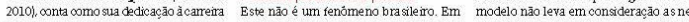

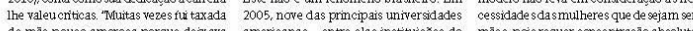

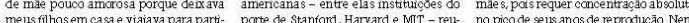
cipar de congre ssos. Mas nenhum deles niram-se para lançar um documento on- daquelas que saa divorciadas ouviuivas ficcul louco", relembra, divertida. Me smo de reconheciam "a necessidade de tomar tèm que arcar oom as obrigazóses domés

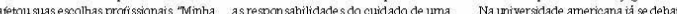

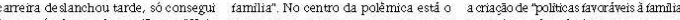

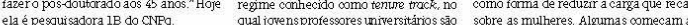
Na éroca, ela optou por levar os stilhos submetidos a um estígogo probatónio de

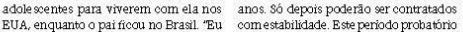

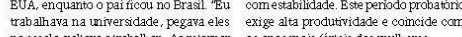

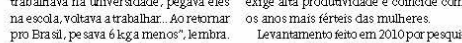

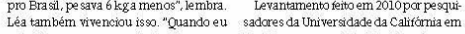

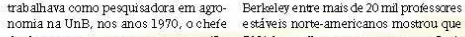

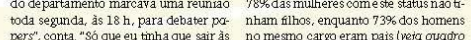
$18 \mathrm{hi} 15$ para pegar meu filho na esola. Era cabcisol. A disparidade reflete as difieren-

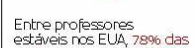
estiveis nos EUA $78 \%$ da
mulheres que chegaran

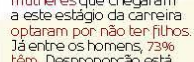

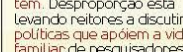

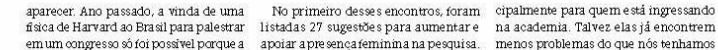

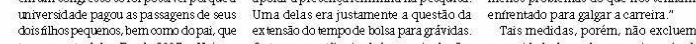

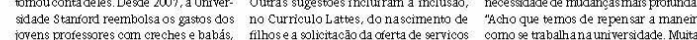

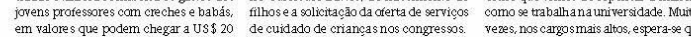

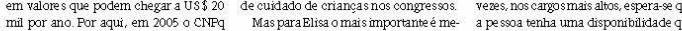

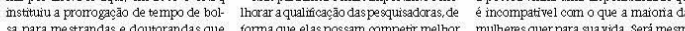

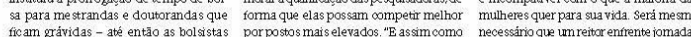

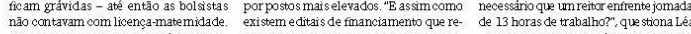
Ano passado, a Capes adenu a medida servam $30 \%$ dos recursos para pe squicsas "O que precisa mudare o sensoccomum

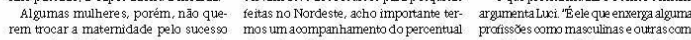

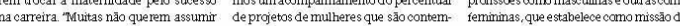

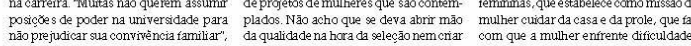

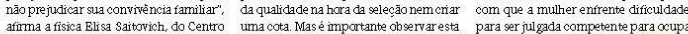

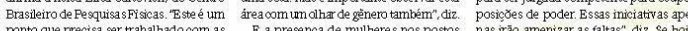

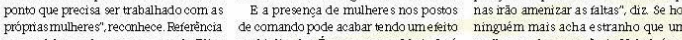

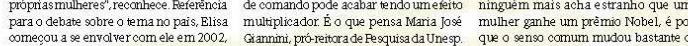
quando foci convidada a daruma pale stra "A essolha de quatro mulheres para as pró- Marie Curie para cá. Talvez seja precis

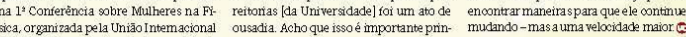

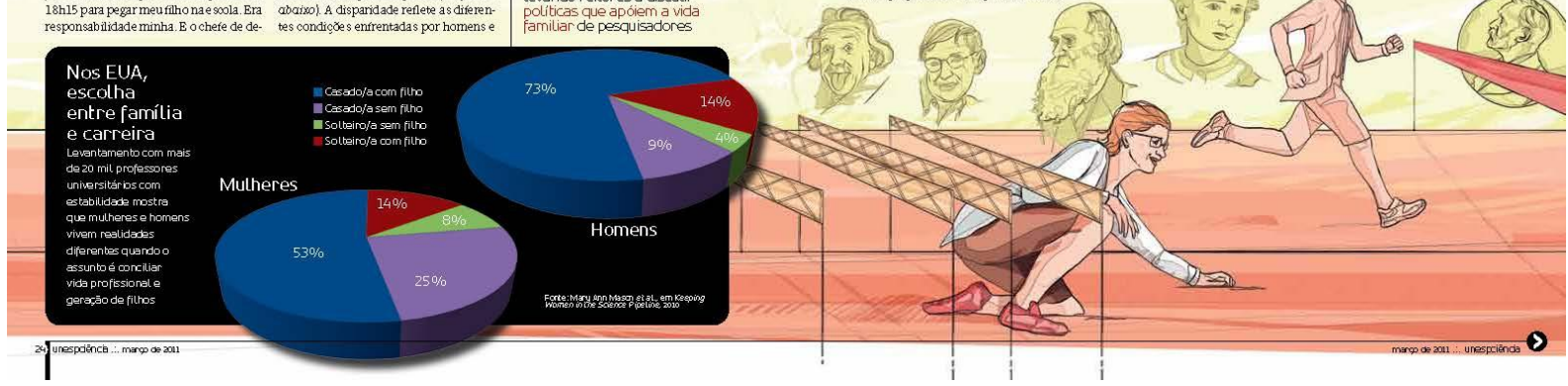

Disponível em: http://seer.fclar.unesp.br/casa 